\title{
ECOLOGICAL ACTIVISM AND AN INTERRELIGIOUS DIALOGUE OF LIFE - A CASE STUDY OF THE SOUTHERN AFRICAN FAITH COMMUNITIES ENVIRONMENTAL INSTITUTE
}

\author{
Annalet van Schalkwyk \\ Department of Christian Spirituality, Church History and Missiology \\ University of South Africa
}

\begin{abstract}
An important theological dimension which unfolds from the Christian Faith and the Earth project is that of interreligious dialogue in relation to the ecology and the ecological crisis. A global responsibility for the earth community - and a global ethics of - care for humanity and the earth may indeed form the basis - or the common ground - for interreligious dialogue. In this article, I use an 'encounterology' approach to investigate the dialogue of life, religious experience, theology, and action, that takes place in the Southern African Faith Communities' Environment Institute (SAFCEI). I conclude that the establishment of SAFCEI and its work creates space and impetus for interreligious earth dialogue as prophetic witness in Southern Africa.
\end{abstract}

Key Words: Ecological Activism; Interreligious Dialogue; Encounterology; Christianity; Baha'i, Islam

\section{Introduction}

During my involvement in the Christian Faith and the Earth project, ${ }^{1}$ which is so important for a revision - and a revival- of Christian theology in a time of human-induced ecological crisis; my original intention and wish to make a contribution with regards to the importance of interreligious dialogue for this project became strengthened. This connected well with my interest in the Southern African Faith Communities' Environmental Institute (SAFCEI) and led to my research on the interaction between interreligious dialogue and ecological action within SAFCEI. ${ }^{2}$

This interest was influenced by my personal exploration ${ }^{3}$ of how the revival of religious traditions and spiritualities in our time can help us find an ecosystem of religions; which

1 I was part of the Christian Faith and the Earth research project from the end of 2009. I formed part of the sub-group on interreligious dialogue.

2 This was also true for my individual response to "The journey of doing Christian ecotheology" exercise, which was also part of the Christian Faith and the Earth project. "The journey of doing Christian ecotheology," as well as my own and other participants' responses to this document, is published in Theology, January/February 2013 issue (Vol. 116 No 1). My response is called "A place where we all stand together: The new creation story as opportunity and imperative for interreligious dialogue".

3 See my following articles: "Women, Ecofeminist theology and sustainability in a post-apartheid South Africa" in Journal of Theology of Southern Africa, No 130, March 2008:6-23. 
allows for an interdependence of what I believe is the life-giving 'roots' and the liberative 'wings' of religious traditions (despite those aspects of religions which are oppressive and divisive).

This interdependence of the different religious ecosystems so as to form an earth ecosystem of religions is necessary so that the wisdom and ethical resources of different religions from across the world can complement each other, in a joint search for 'peace for life ${ }^{4}$ for all of human and other-than-human life on earth. ${ }^{5}$

This practice of ecological theologies in an ecumenical environment also resonates with the encounterology approach to the study of interreligious dialogue that we use in the Missiology Discipline at Unisa.

\section{Searching for an Ecology of Religions: A Global Responsibility}

The re-evaluation and 'revival' of all religions in relation to a global responsibility for the earth community - according to Hans Küng ${ }^{6}$ - are essential if we as human members of the community of life wish to find a way ahead and form some part of a hopefully sustainable future in this time of ecological crisis and global warming. It is also important to find an interconnected ecology of religions across the globe, which will, through the resources of various religions in different cultures and contexts in many parts of the world, contribute to a 'world ethic' and a world view orientated towards ecological care, justice and sustainability.

A global responsibility for the earth community and a global ethics of care for humanity and the earth may indeed form the basis - or the common ground - for interreligious dialogue. $^{7}$ At the same time, a contemporary insight into the origins of the universe and the earth, how the ecological systems of the earth developed and functions, how we are dependent on it and how the human destruction of these fragile systems are bringing about disastrous results for not only the ecology but also for human society, forms a common

"Sacredness and sustainability: searching for a practical eco-spirituality" in Religion and Theology,

Vol 18/1-2, 2011:77-92.

"Welfare, wellbeing and the Oikos Cycle: an Ecofeminist ethical perspective of care", in Journal of Theology of Southern Africa, No 142, March 2012:98-119.

4 In the "People's Chapter on Peace for Life" adopted by a workshop of Peace for Life - a people's forum and movement for global justice and peace - in November 2008 in Hwacheon, Korea, the term 'peace for life' was described as follows: "Peace is the condition for the fullness of life, just as justice is the precondition for peace. Peace ensures the harmonious living of all humankind and creation. In essence, peace is the defence of human dignity and the integrity of the cosmic order of living beings." Accessed on 10/13/2013 at http://waccglobal.org/images/stories/website/programme/communication_for_peace/peace-for-lifecharter.pdf.

5 The term ecology of religions relates to the premise behind the Forum on Religion and Ecology, namely that “... No one religious tradition or philosophical perspective has the ideal solution to the environmental crisis. Our approach emphasizes plurality because perhaps we need to recognise that diversity in life forms in sustained bioregional habitats, and in cosmological thinking is necessary... as a means of finding more adequate cosmological perspectives on nature, as well as for developing more functional environmental ethics” (eds.) Mary Evelyn Tucker and John A Grim, 1994. Worldviews and ecology: religion, philosophy and the environment. Maryknoll, New York: Orbis Books; 11-12.

6 Hans Küng 1991. Global responsibility: in search of a new world ethic. New York: Crossroad.

7 Paul Knitter 1995. One earth many religions: multifaith dialogue and global responsibility. Maryknoll, New York: Orbis Books. 
story of wonder and awe, but also of pathos, tragedy and disaster, that religious people with some ecological awareness may share. ${ }^{8}$

The consequences of ecological destruction challenges Christianity and other religions to 'turn inside out', to turn out of its narrow self-understanding, and to re-orientate themselves within the rapidly changing context of the earth. This also means that Christianity and other religions need to re-orientate themselves towards each other, so as to take joint responsibility for the suffering of all living beings and for the ecological crisis which the earth faces. It is in a global solidarity with the suffering ${ }^{9}$ that people from diverse religions and cultures may start to agree on truth, morality and joint action. ${ }^{10}$

This can only happen in a milieu of ecumenism and dialogue; and with a nuanced and respectful understanding of dialogue - or in very practical terms, encounter - between the great religious traditions and emerging spiritualities. Such dialogue does not mean that religions need to diffuse their own faith convictions. Rather, it creates an opportunity for prophetic witness of the faith that they carry with them; and for a listening and respectful response to the witness of other faiths. Such a respectful encounter may form the basis for a 'face-to-face' and 'shoulder-to-shoulder' dialogue in relation to the challenges which every religion and the whole world community face, in terms of the ecological crisis.

\section{The Southern African Faith Communities' Environment Institute (SAFCEI)}

When the Southern African Faith Communities' Environment Institute (SAFCEI), a multifaith organisation working for eco-justice in Southern Africa, was established in 2005, I was excited and interested. SAFCEI's vision and work clearly was related to my own research interest. Over the years, I have tried to stay in touch with SAFCEI's work and I observed how it became a growing organisation with a strong public presence, in a time where non-government organisations and faith-based organisations have suffered badly as a result of the financial and donor crisis. In South Africa, SAFCEI's prominence in relation to other environmental organisations such as EarthLife Africa, Environmental Justice Networking Forum, Wildlife and Environmental Society of South Africa are growing by the day.

To introduce SAFCEI, I wish to present part of SAFCEI's mission statement: ${ }^{11}$

\section{SAFCEI is committed to cherishing the earth.}

We are an institute of people of many faiths in Southern Africa, united in our diversity through our common commitment to earthkeeping. Our aim is to support the faith communities in fulfilling their environmental and socio-economic responsibility.

In the spirit of our respective faiths, through collaboration, networking, research and action, our objectives are to:

Knitter, One earth many religions, 117-124.

Knitter

Knitter, One earth many religions, 54-66.

See SAFCEI's website: www.safcei.org.za. 
- raise environmental awareness

- engage in formulating policy and ethical guidelines within our faith communities

- facilitate environmental responsibility and action

- confront environmental and socio-economic injustices.

- support environmental training and learning. ${ }^{12}$

SAFCEI, as an organisation which is at the forefront of the renewal of major faith traditions' commitment to earthkeeping and ecological activism, was in a sense an affirmation of my own 'instinct' that:

Faith traditions and individual religious/spiritual people need each other to develop interlinked 'ecosystems' of faith and ethics, which are in conversation with each other so as to change the lives of religious people themselves and to play a public role to change the larger society in relation to the ecological challenges of our time.

For quite a while, I had a sense of urgency to test my 'hunch' and to understand how this dialogue happens practically, where it starts, what dimensions and dynamics what it entails, how it affects society, and its implications for the contemporary ecumenical eco-theological project.

My participation in the Christian Faith and the Earth project afforded me the perfect opportunity to do this. In the months before the concluding conference of the project, which would be held at the Sustainability Institute outside Stellenbosch from 6 to 10 August 2012, I therefore embarked on a research project of limited scope on interreligious dialogue and ecological activism within SAFCEI.

\section{A Research Project Informed by Teaching 'Dynamics of Interreligious Encounter'}

This research project was informed and stimulated by my teaching, at Unisa, of a third year level module called 'Dynamics of interreligious encounter', ${ }^{13}$ which helps the student and the teacher to come to understand interreligious encounter, not only in terms of a theoretical knowledge of the theology of interreligious dialogue; but more specifically in terms of one's

- self-reflexive attitude towards,

- contextual understanding of,

- theological reflection on

- and practical engagement in dialogue with people of other faiths - in various life situations and through different practical approaches to interreligious encounter.

My application of this approach to interreligious dialogue places this article within the central ambit of missiology, as we practice it at Unisa. ${ }^{14}$ For us, encounter and dialogue

13 This module was originally developed, and the study guide was written, by Dr Madge Karecki, who was with the then Department of Missiology from 2000 to 2005. The study guide, "Dynamics of interreligious encounter", was published by Unisa Press in 2001.

14 Here I am referring to the group of colleagues in the Discipline of Missiology, in the Department of Christian Spirituality, Church History and Missiology at Unisa; and the contextual approach that we have been using in 
within a praxis approach is fundamental to missiology as a discipline. Missiology is 'encounterology' - a term coined by Klippies Kritzinger ${ }^{15}$ - a critical study of how Christians respectfully and transformatively encounter 'others' in a consciously contextual approach. $^{16}$

The unique role of missiology in relation to other theological (and social scientific) disciplines is to reflect on all the factors shaping the intentional encounters between followers of different religious ways ... this is what a missiological approach wishes to achieve in response to the challenge of other religions: an informed and respectful faith-tofaith encounter that happens 'uncushioned' face-to-face. ${ }^{17}$

In another publication, Kritzinger ${ }^{18}$ continues to speak of face-to-face dialogue with the dialogue partner, but also internally, of a face-to-face encounter with oneself, as outwardlydirected and inwardly-directed relationship and commitment. This requires a conversion to, and a commitment to, the relationship of dialogue itself. He also speaks of shoulder-toshoulder dialogue in a shared solidarity with the dialogue partner while engaging the same challenges in the larger society; and back-to-back dialogue, when 'witnessing' to one's own community about the integrity of the dialogue partner. All of these forms of dialogue will become relevant in this article.

This mutual encounter happens between people of different contexts, faiths, sociopolitical and economic viewpoints, people from different cultures, genders and sexual orientations, and also between humanity and (the rest of the) ecology.

Interreligious dialogue in this context compels one to learn and to understand more of the holiness and integrity of the whole ecology by sharing the wisdom of other religions' and cultures' insight into the ecology. A revival of one's faith is brought to the open through one's encounter with the ecology. At the same time one is in an encounter with one's partner in interreligious dialogue, who is also urged, in the context of a world in ecological crisis, to search for a revival of his/her faith in his/her encounter with the ecology. This encounter, in a very real sense, with the living and changing ecosystem of another religion in an atmosphere of mutual transformative rediscovery of the earth ecosystem and of the cosmos, can only help all of us to come to serve the 'peace for life' of the entire community of living beings.

\section{My Practical Research Method}

I investigated some of the patterns of encounter between a few leading participants in SAFCEI by applying Kritzinger's encounterology approach. I 'unpacked' the different

our missiological research and teaching, over a number of years. We first worked with the well-known Pastoral Cycle of Joe Holland and Peter Henriot which they presented to the theological world in their book Social Analysis: linking faith and justice. Maryknoll, New York: Orbis Press 1983. We are now starting to use and further develop the approach that our senior colleague, Prof Klippies Kritzinger, has developed from the Pastoral Cycle and what he coined, 'encounterology'.

Kritzinger, JNJ 2008. "Faith to faith - Missiology as encounterology”. Verbum et Ecclesia, 29(3):764-790. From our pamphlet which introduces our missiological approach to students and those interested. Published by Unisa in 2004 .

17 Kritzinger, Missiology as encounterology, 770.

18 JNJ Kritzinger, "Interreligious dialogue: problems and perspectives - a Christian theological approach", Scriptura 60, 1997:47-61. 
Van Schalkwyk

dimensions of these encounters, by using the different phases that Kritzinger identified in the encounterology approach. ${ }^{19}$

- Agency

- Context analysis

- Spirituality

- Theological reflection

- Practical engagement/projects

- Reflexivity

These phases are much the same as the phases of insertion, analysis, theological reflection and planning for action which Holland and Henriot used in their well-known Pastoral Cycle and which is often used in a praxis approach to theology. Kritzinger adapted this further so as to be more useful - in particular contexts in which mission of various kinds are practiced. I will explain these phases as I analyse the interviews with the SAFCEI Board members.

I had in-depth interviews with three members of the SAFCEI Board, representing three of the faith traditions represented on the Board, namely Christianity, Baha'i and Islam. The following faith traditions are represented on the Board: Islam, Baha'i, Judaism, Hinduism and Christianity. Due to time limitations and the limited availability and proximity of representatives of these traditions, I could only manage to conduct interviews with representatives of three of these traditions. These were Bishop Geoff Davies of the Anglican Church in Southern Africa (Christian), Rev Glynis Goyns of the Uniting Presbyterian Church in Southern Africa (Christian), Ms Tahirih Matthee of the Baha'i faith community in Southern Africa, and Sheik Dr Muhammad Ridwaan Gallant of the Muslim Community in the Western Cape. I had the good fortune to conduct face-to-face interviews with Bishop Geoff Davies, Ms Tahirih Matthee and Sheik Dr Muhammad Ridwaan Gallant; and could transcribe these interviews and present them in this article with the permission of the research participants. I had an ongoing e-mail conversation with Rev Glynis Goyns, and received invaluable feedback from her on the inner workings of SAFCEI. This informed the writing and re-writing of this article in a number of places. My research participants were from the Abrahamic faith traditions - of which the Baha'i faith can be described as a 'new' member, although it has some important differences with the 'older' members of this group of faith traditions. Unfortunately I was not able to have an interview with a representative of Judaism.

I explained to all the participants that what interested me about SAFCEI was that people of different faith traditions were coming together to deal with the challenges of the ecological crisis practically; but also that there is a huge religious motivation for the work. What interests me as a theologian is to understand in greater depth how this interaction between action and (inter-)religious motivation happens; how this may result in various forms of interreligious encounter; and how this interreligious encounter may again influence the practical work, as well as the vision and mission of SAFCEI.

In the light of this introduction, I posed the following specific questions to the interviewees: 
- How did SAFCEI happen? How did - and does - the awareness of the ecology bring all the participating faith communities together in SAFCEI?

- What forms of dialogue do you see happening in SAFCEI?

- A 'day-to-day' dialogue of life (sharing the lives and some daily religious practices of people from different faith traditions)?

- A dialogue of action (how you share your joint 'inward' and 'outward' activist work in your faith communities and the broader society, in a 'shoulder-to-shoulder' approach?)

- A 'face-to-face' dialogue of theological exchange (sharing from your theological resources as they relate to the ecology)

- A dialogue of religious experience (sharing prayer and spirituality as they relate to your work and to the ecology).

These were the central questions research questions that I used to interact with four members of the SAFCEI Board - with the pre-understanding that I would not 'enforce' these questions in a rigid manner, but that posing these questions may lead to an open conversation. The introduction of my approach together with the interview questions lead to quite in-depth and even intense conversations between the interviewees and myself, which gave a strong qualitative dimension to this project.

As the interview sessions did not allow enough time for me to explore the teachings of the research participants' religious traditions as these relate to their ecological reinterpretations of their traditions, I had to do some more research so as to understand this dimension better. This is reflected in the paragraphs following on the transcriptions of the interviews.

\section{To put Things in Perspective: Starting with Bishop Geoff Davies, Founder Of SAFCEI}

I present my interview with Bishop Geoff Davies at the beginning, so that his response as founder and Executive Director of SAFCEI can put the story of SAFCEI in perspective.

I started by telling him what my interest in SAFCEI was about. I also said that I find it appropriate to refer to SAFCEI which is a pioneering multi-faith environmental organisation in South Africa when, in the context of the Christian Faith and the Earth research project, I present my reflections on ecology and interreligious dialogue.

I then asked Geoff how all this had come about. How did the vision of a multi-faith environmental organisation come to him? He responded: ${ }^{20}$

To be honest, the inspiration didn't come from me. I wanted to establish an ecumenical Christian environmental organisation for the churches in Southern Africa, but a 'God incident' resulted in this plan going beyond my initial vision. At the time, I was on the South African Council of Churches' National Executive Committee. While there, I retired from my diocese, and wanted to pursue my wish to establish such an ecumenical body. I met up with an old friend from my Pondoland days, Eddie Russell, who worked for the Environmental Development Programme with me on matters such as opposing the development of a toll road through Pondoland. I said that I wanted to get the churches involved in this ecumenical environmental work, and suggested that we have a national 
conference to see whether this idea would get support. He arranged for us to apply for funds from the Global Environmental Facility (GEF)'s Small Grants Programme. In that process, the people from GEF said, "Don't you think you should be multi-faith and have all the religions involved, from the inception of such an organisation?" I agreed. From the start, from the opening conference, we were just convinced and overwhelmed by how right it was to involve all the religions. What is fascinating to record is how grateful the other faith communities were that they have been included and recognised and honoured. For so long, there has been a sense of arrogance on the part of the Christian communities in South Africa towards other religions. Suddenly we were listening to the other religions and hearing them, so it was really a time of honouring one another. Honouring, and enormous gratitude. So then we came out with the strong conviction that this is the right thing to do. We've been growing in this conviction ever since. We've been continuing to recognise and rediscover that all our faiths, in our sacred scriptures, teach that we should cherish the natural environment. We are enriched and our understanding is deepened by learning this from all the faiths. I also think that our understanding of the world, the earth and the environment is deepened by each other.

Our main purpose is to build solidarity between the different faiths in our overriding commitment to cherish mother earth (as we say in our vision statement). That is the uniting factor. We are all part of this planet. There are no Muslim lakes and Christian trees. So this is more a practical solidarity than a theological one. But the theological interchange happens definitely. And we are carried by each other's faith. We keep reminding ourselves in our Board meetings that we are inspired by our faiths, and that we are not just another environmental organisation.

For me to write the present article, I needed to be able to relate what the eco-theological background of an individual and his/her faith tradition is to his/her reflection on interreligious dialogue in SAFCEI, without trying to undertake another in-depth research project into the specific faith tradition. The challenge was to pick up some of the salient themes from a tradition different than my own, which seems relevant for this research. In the case of Geoff Davies, I could go back to a previous interview that I had with him in $2006,{ }^{21}$ when he spoke to me about where his activism began and how his activism was motivated by his spirituality and theology. He spoke of the sense of wonder at the beauty of God's creation that he always had, and how aware he is of God in nature and in the wilderness. On the other hand, he saw what destruction human beings are bringing about in the environment; and he realised very clearly that God's justice extends to the totality of God's creation and not only to human beings with their very anthropocentric view of God's work. This two-pronged awareness of, on the one hand, the wonder of God's creation, and, on the other hand, of the injustice that human beings are committing towards creation, prompted Geoff into action. What also struck me, from that interview, was how aware he is of the intertwined nature of political, economic, and ecological justice. He referred to the Kenyan Nobel Peace Prize winner, Wangari Maathai, who saw those connections so clearly: if we want peace, we need a democracy that works, AND we have to look after the ecology and share natural resources equitably.

Geoff is strongly influenced by the central theme from Thomas Berry's work: We have to stand back from our traditional way of practicing our faith so that we can read the 
'second book' 'written' by God, that of the evolvement of creation. ${ }^{22}$ By doing so, we can find our true place in the creation story. This may give us a new point of view on our anthropocentric views and destructive practices and will enable us to reform these practices.

He expressed his theology of religions in the following words: "If we can recognise God, this Creator God, at the centre of what we are doing, then we are much more unified, there is a sense of unity with the Muslims, the Jews, the Hindus". Geoff told me that he was influenced by John Hick who was one of his lecturers, when he was studying at Cambridge in the 1960's. John Hick proposed in his pluralistic hypothesis that each world faith is a separate, culturally conditioned way to view and to experience the one Ultimate Reality. As he states in An Interpretation of Religion, "These traditions are accordingly to be regarded as alternative soteriological 'spaces' within which, or 'ways' along which, men and women can find salvation/liberation/ultimate fulfilment". ${ }^{23}$

Geoff also has an ability to appreciate and use liturgy - and the liturgical programme of the year in specifically the Anglican Church of Southern Africa - to convey the different 'seasons of creation' and how these relate to, for example, the protection of water resources biodiversity, climate change, and so forth. ${ }^{24}$

\section{Tahirih Matthee (Baha'i, Chairperson of the Board of SAFCEI)}

My second respondent was Tahirih Matthee, who is the Chairperson of the Board of SAFCEI. She found my questions far too academic and theoretical, and surprised me with her own very wise take on these questions. As we started to interact, I guessed that she 'saw through' my efforts to ask questions which would serve my own rather lofty, too ambitious aim with 'my' research project, aims which were perhaps disconnected from her practice of interreligious encounter. She responded to the research questions from a place of deep spirituality and humility. She overwhelmed me when she started by asking, playfully, what questions would God ask, if He would have done this research? Then she went ahead to speak about her impressions of the encounter between the SAFCEI members themselves, and between them and role players in the public domain who are involved with matters of ecological importance: ${ }^{25}$

From a spiritual dimension, I would be thinking about these questions in terms of depth.

I'd say we're in a lot of trouble if we don't understand the importance of being humble, in the sense that none of us can afford to come to this work ever having an iota of a lingering idea that our particular faith community has the answer or that a particular faith community on its own is going to get it right. So I think the lessons that I am beginning to learn from just a small journey with SAFCEI is that, first of all, one has to learn to genuinely love God's creation, to genuinely love others. To genuinely put

This theme is addressed in various ways in various publications of Thomas Berry. I would like to refer the reader to one of these publications: Thomas Berry (edited by Mary Evelyn Tucker). Evening thoughts: reflection on earth as sacred community. San Francisco: Sierra Club Books, 2006:18-20.

23 John Hick, An Interpretation of Religion: Human Responses to the Transcendent, 2d. edition, New Haven: Yale University Press, 1989:240.

24 Geoff Davies and his wife, Kate, made a huge contribution to writing and compiling the Season of Creation resource book, to be used for six weeks in the liturgical year of the Anglican Church in Southern Africa. Authorised for us in the Anglican Church of Southern Africa by the Provincial Liturgical Committee and the Synod of Bishops. Typesetting and Layout: Ikhala Graphic Communications. Published in 2008. 
oneself lower than the other, not demeaning oneself, but learning to create an enabling space where the other voices can come in. The problem that I see in the world is that, because people don't listen to each other, especially regarding the economy and the environment, we are in the problems that we are in.

In SAFCEI there is a continuous debate and questioning about understanding the ecology, ecological problems, focus areas - for example: Why are we focussing so much on climate change? Shouldn't we rather focus on biodiversity? Or what do we mean when we speak about 'living beings'? Then why do we eat meat here today? We are very good at critiquing, and then we create a space of openness in which to interrogate a matter. We don't always find answers or alternatives so easily, but that is the journey we are on.

A huge question we face, is: If we are an organisation of people of faith who make a public stand on issues like climate change, reducing our carbon footprint and clean energy, who engage with politicians and law makers to consider these matters when writing an Energy Bill or on their plans to build nuclear power stations; then we have to show other organisations in society that we are getting our own house in order. If the major faiths in South Africa, with the strongest congregations, are unable to show that we have started the journey of change from within, then we are in for a bit of trouble. Other activists, government, whoever, can wag their finger at us and say, it is all good and well that you can advocate for clean energy, but we would like to see what you have been able to change in your own circle. SAFCEI is now starting to get established with some wonderful people working together, a growing network and a user-friendly website so we seem to have a growing presence. But a great part of our journey is to the inside, towards our own faith communities, to effect change there. We are going to be measured by our own actions.

If the faith communities start living closer to the ecology, you are also living closer to God and closer to other people. The inner relationship to God becomes manifest.

As I see it, our core work is our eco-congregations where e.g., the Muslim community can reflect practically on what the Qu'ran says about the ecology, and the Christians on what resources the Bible holds for living in an eco-congregation. The inner conversation between Muslims and Jews and Christians on the eco-congregations are hugely encouraging to the SAFCEI members. It is also the theological and spiritual resources of the different faith communities in SAFCEI that serves as encouragement to one another.

There is this one story of a mosque, which is very interesting. The Muslim people pray five times a day and they wash their hands every time. I was really moved when I learned, at a specific mosque, that the water that they use from the ablution is then channelled into a garden. How creative! Then I was immediately thinking of the Baha' $i$ Headquarters on Mount Carmel, and how our architects designed those gardens so that the water is being taken care of and re-used all the time. So the Muslims using the water from the ablution for the garden is very significant. I was thinking of the spiritual significance of somebody washing her hands and while this water is flowing, this person is praising God, and that water is flowing into the ground. I imagined how profound if I would eat a vegetable or a fruit that comes from that soil. Stories of even the small efforts to make a change, have a profound effect and influence on one's own thinking.

This inner witness to each other serves as encouragement and accompaniment. This would be my Baha'i take on the Christian concept of witness. You need to be an embodiment of love to be able to witness by encouragement and accompaniment. If a member of SAFCEI has to go back into his/her faith community with, for example, the 
idea of the eco-congregations, he/she will need to be accompanied by other members. Faith communities often have deeply entrenched practices and systems, and it is not easy to make inroads into these systems. We as members of SAFCEI have to accompany one another to bring about change in a specific faith community.

I did not have time to interact with Tahirih about the teachings of her tradition, and how these could be re-interpreted in an ecological era. So I had to do some additional research on the Baha'i faith, afterwards.

At the heart of the Bahá'i faith is the conviction that humanity is a single people with a common destiny. In the words of Bahá'u'lláh, the Founder of this Faith: "The earth is but only country, and mankind (sic) its citizens". Their prophet, Bahá'u'lláh, who lived in Persia during the $19^{\text {th }}$ century, taught that there is but one God who progressively reveals His will to humanity through the messengers of God from all the different great religions: Moses, Krishna, Buddha, Zoroaster, Jesus, Muhammed; who represent successive stages in the spiritual development of civilization. Bahá'u'lláh, the most recent Messenger in the line, has brought teachings that address the moral and spiritual challenges of the modern world. If heard, these messages may lead humanity forward to realise the purpose given by God to the human race: to carry forward an ever-advancing civilization in harmony with the natural world. ${ }^{26}$

This vision of the oneness and interconnectedness of all religions enables the Bahá'i to develop an important perspective not only on the evolution of the natural world, but also on what ecological wholeness and sustainability might entail. They have a necessary message about the protection of the environment and the conservation of the earth's resources, from which people of other faiths may learn a great deal. What interests me is that they have an understanding and appreciation of not only the emergent nature, but also the interconnectedness of the world religions. Such a sense of the interdependence of religions may assist religious people to develop world views which allow for both complexity and holism, and which enables us to live in greater harmony with the earth.

Baha'u'llah challenges humanity to allow God's love and commandments to bear fruit in their lives and to manifest in values and spiritual attributes of dignity, compassion, the willingness to sacrifice, moderation and commitment - and to overcome the greed and malice so pervasive in the contemporary global society.

Baha'u'llah enjoins his followers to develop a sense of world citizenship and a commitment to stewardship of the earth, which are imbued with a deep respect for the natural world and for the interconnectedness of all things. He further teaches that:

Also see: Robert A White. "A Bahá'I Perspective on an Ecologically Sustainable Society" in Worldviews and Ecology: Religion, Philosophy and the Environment, edited by Mary Evelyn Tucker and John A Grim. Maryknoll, New York: Orbis Books, 1994:96-112. 
- Nature reflects the qualities and attributes of God, and should, therefore be greatly respected and cherished,

- that all things are interconnected and flourish according to the law of reciprocity, and that "diversity is the essence of perfection" which allows the whole of life to function efficiently,

- and therefore, human beings should treat every living being with the utmost loving-kindness.

\section{Muhammad Ridwaan Gallant (Muslim Leader and Scholar, Member of the Board of SAFCEI)}

I met Sheik Dr Muhammad Ridwaan Gallant earlier at a conference on urban theology and sustainability, which I co-organised at Unisa. So, I was very pleased that he responded to my enquiries regarding this research project. When I communicated with him during July 2012 he mentioned to me that he was very busy and that he could only meet me between prayer times, as it was the month of Ramadaan. When I met him at his home in Surrey Estate on the Cape Flats, I was privileged to experience the piety and hospitality of Muhammad and his wife Aisha, during this holy month.

I asked Muhammad what he observed around him in SAFCEI, what kind of interreligious dialogue he experienced as happening in SAFCEI. This was his response: ${ }^{27}$

SAFCEI is a broad-based organisation concerning the environment and the protection of the ecology in terms of water, resources, wetlands, everything concerning the environment which is being disrupted. SAFCEI is an organisation where all the religions come together and they take a broad stand together as human beings, although they come from different religions. Different religions teach you about the environment, whether it is Islam or Christianity or Buddhist or Baha'i. One thing is common: we want to protect the environment so that we can spare this world for future generations. Each representative of a religion, at specific events, would draw on their basic religious teachings, and give a perspective on an issue such as global warming, and why it is threatening life on earth, and what a specific religion's ethical response should be. I have experienced over the years that the three Abrahamic faiths, Judaism, Christianity and Islam, have many things in common, also in terms of some commonality in religious texts and allegiances to religious founders and prophets. In this sense, on a theological level, I experience that the teachings on ecology also enhance, support and strengthen each other.

The Muslim community is very much a part of SAFCEI. I belong to the Muslim Judicial Council, and we have an environmental desk which I steer. As a member of the MJC, I have access to the Muslim community and can go to various mosques and link up with them. On Fridays I go to mosques in the Cape Town area and speak on the environment. When I go to the mosque, I speak basically on three things: the protection of our trees, the protection of our water, because in the Muslim community water is used a lot for ablution. I also speak on animal rights and on global warming. The imams are very receptive to my work and also to the sermons that I send out. For me, all of this started with SAFCEI. When I was writing my PhD on sustainable development in 2005, I attended one of the early conferences (or events) in SAFCEI, and met up with Bishop 
Geoff Davis and Ms Tahirih Matthee. From there I took the initiative and we established the environmental desk with the MDC. If it wasn't for SAFCEI, I would just have completed my PhD and be sitting back. Now at least I can do something and get some feedback. The whole idea of SAFCEI to teach people environmental ethics through ecocongregations also took off in the Muslim community. Through the ecumenical and multi-religious conferences in Zambia and Kenya, before the COP17 Summit in Durban in November 2011, I met many other Muslim and other African religious leaders and can now interact with them. I am also in contact with Muslim scholars in Palestine who are at the forefront of re-reading the Qu'ran text from an ecological point of view. These are Fazlun Khalid from London and Mustafa Abu Sway from Palestine.

These researchers have discovered various aspects in our text which relate to the ecology and the ecological crisis. It was always there but we never took notice of it. For example, the Prophet $(P B U H)^{28}$ said, "There is none among the Muslims who plants a tree or sows seeds, and then a bird, or a person or an animal eats from it, but is regarded as a charitable gift for him". ${ }^{29}$ This is what I draw on when I teach at the mosques. The Prophet (PBUH) also said that, "He who cuts a lote-tree (without justification), Allah will send him to Hellfire". ${ }^{30}$ These trees grow in the desert - so that is why they were so precious. Now we only rediscover the importance of this text in the context of deforestation.

In SAFCEI we could work together over a period of time to develop the organisation and its aims and objectives, because the Buddhist and the Muslim are working together for a common purpose, and we share common ground. We work together as SAFCEI friends, with great understanding. We have a common drive coming from our various religions, and a common aim, namely, a sustainable future.

One of the main aspects of Islamic eco-theology that struck me was Islam cosmology - the relation between God, humanity, the earth and the cosmos. God is the Creator of heavens, humanity and earth and the ultimate holder of dominion over the creation. All created things return to him and are accountable to God in their own ways. Creation, in all its myriad diversity and complexity, may be regarded as a vast array of 'signs' of God's power, wisdom, grace, and majesty. The whole creation praises God by its very being (Sura 59:24, ${ }^{31}$ compare with 64:1). ${ }^{3233}$

God reigns over humanity and nature and humanity has been given a position of viceregency or stewardship of God on earth - and in that sense has authority over nature. Human beings have been privileged to occupy a position even higher than the angels as the vice-regents or stewards of God on earth. Yet, according to the Qu'ran, they share with all

PBUH is the abbreviation for "Peace be upon Him".

Bukhari 1986:vol 3:295 no 2320.

Abu Dawud-Abi Tayeb: 1990: Vol. 7; Book no 14:102. This text forms part of the sayings and narrations from the Prophet (PBUH) or his practical applications, which is regarded as the second source of reference, after the Qu'ran.

31 Surah 59:24: He is Allâh, the Creator, the Inventor of all things, the Bestower of forms. To Him belong the Best Names. All that is in the heavens and the earth glorify Him. And He is the All-Mighty, the All-Wise.

32 Surah 64:1: Whatsoever is in the heavens and whatsoever is on the earth glorifies Allâh. He is the dominion, and to Him belong all the praises and thanks, and $\mathrm{He}$ is able to do all things.

33 I consulted an article, Islam and ecology: a bestowed trust inviting balanced stewardship by Frederick M Denny on the website of the Forum on Religion and Ecology,

http://fore.research.yale.edu/religion/islam/index.html; accessed on 24 November 2012. 
animals an origin in the common substance, water (Sura 24:5 $5^{34}$ and Surah 21:30) ${ }^{35}$ and they will return to the soil and the earth, as will other creatures. For me it was fascinating to read that the creation of the cosmos was a greater reality than the creation of humankind (Sura 40:57). ${ }^{36}$ Could this narrative of humanity's creation which is in a sense being overshadowed by the creation of the cosmos, inform Christian eco-theologians?

In this cosmology, there is the greatest of sense of unity (tawhid) between God and every mode of being and knowledge. Regarding humanity's role of khalifa (trustee) over nature: I still have concerns regarding the possible exploitative implications of human trusteeship for the earth in a religion that is broadly speaking, very much like mainline Christianity, not sufficiently ecologically-orientated. Yet, I also recognise that trusteeship has a much more positive meaning in authentic Islam theology than what it had in some historical forms of Christianity as this relate to human exploitation of nature. The preeminent scholar Seyyed Hossein Nasr $^{37}$ understands humanity's vice-regency as part of the spiritual restoration of humanity who has overcome its disharmony with the environment. For Nasr, the human destiny entails fulfilling the role of God's viceregent on earth and protecting the natural order, thus bearing witness to the truth that the whole of nature speaks of God.

Something else that struck me is the importance of purification for believers, in their preparation for prayer. This speaks to the sacredness of not only water as a resource for the worship of Allah, but also of the importance of (pure and unpolluted) water for all of life and for the protection of the ecology. In my conversations with both Muhammad and Tahirih, the central role of water in an ecological awareness in Islam came to the fore. This was demonstrated beautifully by Tahirih's narration of the story of the mosque where the water used for ablutions was channelled into a food garden.

\section{Understanding Interreligious Dialogue in SAFCEI by Means of the Encounterology Model}

Interreligious dialogue allows for the proclamation of the specific message of faith from the dialogue partner from another religious tradition, towards the Christian - or Muslim - or Baha'i - dialogue partner. This, again, leads to a reciprocal proclamation of faith from the receiving dialogue partner, and thus, a safe circle for - or cycle of - dialogue is created. Discovering the other, in interreligious dialogue, allows for the discovery of new depths and possibilities in oneself. In ecological terms, it allows for the connection with new sources of life and nurturance within oneself. How does this happen in SAFCEI? How does encounterology, the art of encountering each other in a spirit of shared dialogue, create the united piece, then we parted them? And we have made from water every living thing. Will they not then believe?

36 Surah 40:57: The creation of the heavens and the earth is indeed greater than the creation of mankind, yet most of mankind know not.

37 I consulted an article by Marjorie Hope and James Young in Crosscurrents, http://ww.crosscurrents.org/islamecology.htm, accessed on 21 November 2012, in which they interacted with the thought of Seyyed Nossein Nasr. Important works of Nasr include The Spiritual Crisis of Modern Man (London: George Allen and Unwin Ltd., 1968); Knowledge and the Sacred (Albany: State University of New York Press, 1989); and Traditional Islam and the Modern World. London: Kegan Paul, 1987. 
conditions for mutual witness and collaborative action? How does face-to-face dialogue lead to shoulder-to-shoulder and back-to-back dialogue in service of justice and 'peace for life' for the whole community of living beings?

I am now going to use the seven dimensions of interreligious praxis as encounterology, identified by Kritzinger (Faith to faith: mission as encounterology, p 5) as a guideline to try and discern some of the patterns of interreligious dialogue within SAFCEI:

- Agency: Where do I come from, and who am I in relation to the interreligious dialogue partners in SAFCEI?

Starting with Geoff Davies, it would be accurate to say that he went into this encounter as pioneer activist for eco-justice and sustainability through his work in the Anglican Church in Southern Africa. This started with his groundbreaking work in the Diocese of Umzimvubu, where he and his wife, Kate, worked at grassroots level with the parishioners and communities within the diocese with environmental education, work to establish sustainable income generating projects, and action to protect the Wild Coast. He eventually became a member of the South African Council of Churches' National Executive Committee. As pioneer and leader, he had the stature to establish the Southern African Faith Communities Environment Institute, while being prompted by the people of the Global Environmental Facility's Small Grants Programme to go one step further in his vision so as to establish an interreligious institute and not only an ecumenical Christian institute. His own theological background and his openness towards people from different religions enabled him to recognise the 'God moment' of the decision to establish an interreligious institute, and to recognise the spirit of openness, gratitude and oneness of purpose among the leaders from the different faith traditions who were part of the founding of SAFCEI.

Tahirih Mathee is a leader in her own right in the Baha'i Community in South Africa and also an active member of the Western Cape Religious Leaders' Forum. She is inspired by the world-embracing vision of Bahá'u'lláh regarding the oneness and interconnectedness, not only of humanity, but also of religions. This goes along with the strong ethical and spiritual base of her tradition's engagement in any work for the betterment of humanity and for the sustainability of the planet. This prepared her to be the Chairperson of the SAFCEI Board, a task which she executes with wisdom, spiritual depth and a comprehensive understanding of the task at hand.

Muhammad Ridwaan Gallant is a leader and a scholar of the Muslim community in the Western Cape, a member of the Muslim Judicial Council, and an Islam ecotheologian who communicates with Islam eco-theologians in other parts of the world. As such, he welcomed becoming a member of SAFCEI in 2005, so that he could go back to the Muslim community with a mandate to engage the Muslim Judicial Council with SAFCEI and to become a teacher of ecological ethics and practices at mosques in the Western Cape.

In all these cases, discovering the other, in interreligious dialogue, creates new possibilities. In ecological terms, it connects with new sources of life, by encountering ecologically-aware members of other faith traditions. 
- Context: What are the religious, social, political, economic, and ecological factors that influence the society within which the three different leading members of SAFCEI encounter each other? How do these factors influence their encounter?

All three members of SAFCEI demonstrated a strong awareness of those factors, globally and locally in the global society, which are contributing to the ecological crisis. They are very well informed about the geo-politics and its impact on economy and ecology; the latest developments with global warming and its impact on Southern Africa; the energy industry in South Africa, green energy alternatives, water and wetland pollution, and so forth. As part of the SAFCEI team, they engage with role players within South Africa, such as government officials, other ecological organisations, and religious communities, so as to address the ecological problems that we are facing in Southern Africa.

These experiences equip the three members of SAFCEI to work with the entire fulltime SAFCEI team on these issues. The SAFCEI team researches and debates matters thoroughly before they decide to adopt a specific viewpoint and path of action. This informs all of them to return to their faith communities so as to conscientise and enable leaders and members to identify and address ecological problems in Southern Africa. In this way, the SAFCEI members in the meeting rooms, the offices and at the leadership of faith communities, can support each other when they return to their faith communities so as to raise awareness and mobilise members of local communities to become involved in building eco-congregations or combat the pollution of local wetlands. Collaborative context analysis thus equips them to become mutual witnesses of the restoration of 'peace for life' at global and national levels, as well as to return to their own faith communities to become witnesses and change agents. All in all, this creates a powerful motivational drive for the dynamic work that SAFCEI is doing.

- Spirituality: What kind of spirituality do the three members of SAFCEI practice? Which spiritualities are practiced among the SAFCEI Board members and staff? How do these spiritualities influence their meetings and collaborative work? How does the sharing of these spiritualities deepen the communal practice of worship and liturgy in the shared space of SAFCEI? How is this reflected in SAFCEI's practical work?

(I put 'spirituality' before 'theology,' because of its central role in the life of SAFCEI, and also because it seems to me, so far, that it is at this stage more important than theological reflection for SAFCEI.)

What strikes me from my own interaction with SAFCEI, and from what I read on their excellent website, and what I observed in my encounter with Geoff, Tahirih and Muhamed, is how central their spirituality is in SAFCEI's existence, and in the lives and participation of the three interviewees in SAFCEI. What I can resonate with in terms of Geoff's spirituality, is how his sense of wonder and awe at the mystery and beauty of creation carries his work at all times, and how it informs his sense of outrage at ecological destruction and injustice. Probably, as I could detect in SAFCEI meetings and on SAFCEI's website, these themes of Geoff's spirituality are also present in the whole of SAFCEI and informs both its communal times of prayer and liturgy and its action.

What I observed with Tahirih is how in a very deep sense, her spirituality informs her wisdom, her leadership, her ability to look at the existence and the work of SAFCEI 
in an overarching and coherent manner. Here the Baha'i faith and its teaching of the unity and the interdependence of humanity and religions in the presence of one God, informs not only her own spirituality, but also the way in which she seeks to promote ecological justice and sustainability through her work as chairperson of the SAFCEI Board. Her spirituality manifests in her love and encouragement of SAFCEI's members, helping them to go back to their faith communities and to bring about change in often conservative environments.

I met Muhammad during the time of Ramadaan, a very busy period for him as an imam and spiritual leader, but also a time for fasting and prayer - and hospitality. What beautiful values to translate into one's eco-spirituality and practice! It also struck me how he used the central practices and rites of the Muslim faith to convey the message of the 'greening' of Islam: linking up with times of prayer and teaching at mosques; and taking from the central rite of cleansing, to teach the value and sacredness of not only water, but of the whole ecology - to the Muslim community. His spirituality is one of finding new ecological meaning in his strict observation of the teachings, practices and rites of Islam, and of uncovering the ecological wisdom in the words of the Prophet in the Qu'ran.

Indeed, from all three the interviewees, from my communication with Glynis Goyns, ${ }^{38}$ as well as from what I know of SAFCEI's meetings and what I read on their website, I could detect the following: There is a focus on liturgy and worship; and a sharing of the liturgical times of the year and the religious feasts in the calendars of all the participating religions in SAFCEI, as interpreted from an ecological point of view. This sense of liturgy plays an important role in the organisation. It creates that shared space of worship and of spiritual experience that beautifully brings together meetings, planning sessions, and punctuates the routine of working days and annual programmes, and thereby carries the work of SAFCEI.

There are those members of the Board and the staff of SAFCEI whose natural mode of operation is more contemplative, spiritual and reflective, and there are those who lean towards action and praxis. This ensures that there is constant movement between spirituality and action, and that action is constantly fed by the deep spiritual resources of the SAFCEI family. It is clear from their approach that their ecological activism is possible because they are all people of faith.

- Theological reflection and reflection on interreligious encounter: How do the three members of SAFCEI re-interpret their theological traditions in the light of the ecology? How do they practice - and understand-interreligious dialogue as a source for their ethical and practical work? And how does their practical work inform their reflection on their interreligious dialogue?

As was said by Geoff Davies, SAFCEI is first and foremost an organisation based on 'practical solidarity' between members from different religions whose aims are to "support the faith communities in fulfilling their environmental and socio-economic responsibility" and to engage in environmental action. The theological exchange is definitely present, but it often happens in an informal and spontaneous way; and

38 First e-mail correspondence with Glynis Goyns conducted on 24 July 2012. Subsequent correspondence is dated 4 and 16 February 2013. 
sometimes in a 'preliminary' way in the sense that some planned theological exchange happens - but as a starting point for further activism and public participation in civil society forums and events and not necessarily as a basis for theological dialogue. There are exchanges on religious teachings and practices as these relate to the search for a common ecological ethic. As I have tried to point out in the previous section, the spiritual and liturgical exchange is more likely to be a regular part of the functioning of SAFCEI and this definitely is an important resource for the informal practicing of theology among SAFCEI members. Yet, these theological and spiritual exchanges may be taken forward into a more systematic exploration of the dialogue of theological exchange taking place amongst SAFCEI members.

In saying this, I do not want to convey the impression that there has been no structured attempts to bring different faiths together to engage in a joint interreligious ecotheological reflection, which influenced SAFCEI or in which SAFCEI participated. There are some significant examples of such attempts.

One prime example is the intense debate that took place within the SAFCEI Board just after the inception of SAFCEI - to find a common approach and a common space to work together as representatives of different faiths. There was concern with such forms of interreligious engagement which could result in situations where members use SAFCEI as a platform to proselytise, or where it would be assumed or expressed that religions may 'syncretise' and lose their distinctiveness. Eventually a 'multi-faith' approach was chosen. It was agreed that there should always be mutual respect and acceptance of all the participating faiths with their similarities and differences, allowing a comfortable space for diversity of belief and opinion, rather than seeking a vague sense of unity. This approach proved to be very fruitful over the years. The different members of SAFCEI are at ease with one another and have a sense of being a family, without feeling obliged always to agree with each other. There are also moments when there is an absolute sense of unity regarding shared spiritual and ethical insights or choices for action. ${ }^{39}$ This was indeed one fruitful way of finding the 'common ground' of which Paul Knitter speaks, which is needed for interreligious dialogue and action to address the ecological crisis.

Another area of bringing faiths together is SAFCEI's public facilitation of interreligious encounter in Africa regarding the ecological crisis and global warming - as it affects the African continent. Space does not allow me to mention all the international platforms where Geoff Davies engaged in interreligious dialogue on ecological affairs. What is important to mention here is the three multi-faith conferences which SAFCEI facilitated in the run-up to the $17^{\text {th }}$ Conference of Parties to the UN Framework Convention on Climate Change (shortly referred to as COP17) Summit, held in Durban from 29 November to 9 December 2011. These multi-faith conferences were the Southern African Faith Leaders Conferences in Lusaka, the Pan-African Faith Leaders Conference in Nairobi, and the South African Faith Leaders Conference at Koinonia outside Pietermaritzburg. All these events resulted in public statements, ${ }^{40}$ addressed to

I would very much like to thank Rev Glynis Goyns for sharing these facts and insights with me in e-mail correspondence on 4 February 2013 and during a face-to-face conversation on 22 February 2013.

40 The Lusaka event was attended by Christian and Muslim leaders. The "Lusaka Declaration on Climate Change - May 2011" calls on the South African government and host of COP17 to stand with Africa in the climate negotiations - not with the big polluters. The Pan-African Faith Leaders Conference at UNEP in 
religious and political leaders of Africa, civil society, religious communities and the press. At the South African conference at Koinonia, a petition was drafted, titled "We have faith: Act Now for Climate Justice". It was eventually signed by over two hundred thousand people, including faith leaders of all the major faiths in South Africa, including Muslims, Buddhists, Baha'i, Hindus, Jews and various Christian denominations. The final petition was publically presented by Archbishop Emeritus Desmond Tutu to Ms Maite Nkoane-Mashabana, the South African government's Minister of International Affairs and Co-operation, and Ms Christiana Figueres, Executive Secretary of the United Nations Framework Convention on Climate Change (UNFCCC) at a multi-faith rally at Kingspark Stadium in Durban on 27 November 2011. After COP17, these declarations and petition were distributed widely via the SAFCEI Board Members representing the Baha'I faith, Islam, Hinduism and Christianity, to local faith communities, encouraging them to prompt further discussions and practical work. It is also interesting to note that these processes inspired the Sri Lanka Inter-religious Dialogue on Climate Change and Biodiversity Conservation event which took place from 23-27 September 2012 in Anaradhapwa, Sri Lanka, and which was organised by the International Network of Engaged Buddhists. ${ }^{41}$

Did any further developments regarding local faith community's members' reflection on the relationship between their lives and contexts, their faith and ethics, their relationship to the social and religious 'other' and their relationship to the ecology - as well as a similar reflection on 'leadership' level and on a more formal theological level - take place in the wake of these very exciting interreligious events, and with regard to these events? From my interaction with my SAFCEI friends, I gleaned only that there has not, as yet, been enough space and time allocated to such deep theological reflection and interchanges. 42

It is perhaps the duty of 'professional theologians' such as myself and others to interact with SAFCEI on this terrain, and to identify some of the theological patterns and themes that present themselves in a research 'encounter' such as this? May this be a way of making my humble contribution to the work of SAFCEI? I also need to say that one of my first observations is that a more purposeful interreligious theological exchange in SAFCEI, in terms of the theological riches of the different members' distinct faith traditions and how these may contribute to a stronger and more coherent ecological world view as a basis for a shared ecological ethic, will serve SAFCEI and its constituency well.

There is a great deal that SAFCEI can teach one in terms of interreligious dialogue as 'encounter-ology' and prophetic witness in a time of ecological crisis. All three SAFCEI Board members as well as Glynnis Goyne have spoken on how valuable these exchanges are for continuous dialogue within SAFCEI.

'Encounterology' happens when the members of SAFCEI's understanding of the ecology and the sacredness of the ecology is deepened in their interactions with each

Nairobi on 7 \& 8 June 2011 was attended by 130 faith leaders representing mostly Christians and Muslims, but also African Traditional Religions, Hindus, Baha'I and Buddhist communities from 30 countries across Africa who formulated and endorsed the "Nairobi Declaration on Climate Change".

41 http://safcei.org/wp-content/uloads/2012/03/Sri-Lanka-Interfaith-Dialogue-on-Climate-Change-report.pdf accessed on 17 February 2013. 
other and their different teachings and practices, and when this strengthens their prophetic witness to human society and the natural world.

'Encounterology' occurrs within the family of SAFCEI when the SAFCEI members accompany and support each other, so as to go back to their communities, to educate and assist them to become eco-congregations and agents of ecological action in their immediate surroundings. This becomes necessary as a matter of integrity, since an inner reformation and conversion in terms of sustainable living needs to happen, before presuming that one can be a public agent regarding ecological justice. In this way, the vital links between intra- and interreligious dialogue make the shoulder-to-shoulder dialogue as encounter with society and geo-political powers - and with the earth itself - possible. And perhaps this form of dialogue in relation to the earth requires a new name, namely, earth dialogue.

- Practical projects and activism: What are the practical projects, the programmes and the campaigns that the four members of SAFCEI as well as other members are involved in? How do these projects influence their encounter with each other? How do the practical work and activism influence their spirituality and theology? How do their spirituality and theology influence their practice? Can their theology influence their practice better and more effectively, and vice versa?

As said from the onset, SAFCEI's orientation is in the first place a practical and activist one. This deserves due recognition and respect. Yet, the interaction between action and reflection occurs consistently, and probably much better than what I could detect in this small research project. There is a constant shift between spiritual meditation, theological reflection and practice that feeds the activism of SAFCEI. Although their programmes and individual actions are too many to mention here, the most outstanding ones, as I could detect, are the following: their work with eco-congregations in the various faith traditions; their involvement in the struggle of the communities of Pondoland against the development of the $\mathrm{N} 2$ toll road through this ecologically sensitive area; their participation in the civil society sector of the Congress of the People (COP) Summits on Global Warming and specifically the COP17 Summit in Durban in 2011 through the 'We have Faith' ecumenical campaign; their energy and climate change programme; and their youth ambassador programme. Each of these programmes has dedicated staff members who plan carefully and reflect well on their work, and work with great passion and dedication. As I could detect from my interviews and communication with the four research participants, my exposure to SAFCEI's meetings and their website; these programmes are all informed by the fact that SAFCEI is an organisation of people of faith, whose whole existence is influenced by the mutual sharing and support between the members of different faith communities. What I am not fully sure of, is how consistently and extensively they reflect on the implications of these programmes for their spirituality and theology; and vice versa. This need not be evaluated negatively. There is a spontaneity and depth in their faith reflections and worship which carry their activism.

- Reflexivity: How consistently do the four members of SAFCEI as well as other members integrate the foregoing five questions in their life of faith and practice? Are they learning and growing through this interfaith encounter? Does this reflection lead them to grow into renewed and stronger forms of agency, context analysis, spirituality, theological reflection, and planning for action? 
As I have said with regard to the previous questions, my impression is that there is probably a greater level of reflexivity on the action-theological reflection interrelationship than what I could detect; and this research project's findings may be limited. However, my observation is still that more can be done in terms of greater reflexivity on the meaning of the interfaith encounter taking place among them, on the total scope of their work.

\section{In Conclusion}

The theological project of interreligious earth dialogue as:

- the encounter between members of different faith communities in the sharing of life experiences, worship and spirituality, and ecological activism,

- a practical and ethical response to the ecological crisis as the common ground for interreligious encounter and 'earth dialogue' in the context of the ecological crisis

- a mutual exploration and re-interpretation of the shared but diverse terrains of the world views and basic tenets of faith traditions in the light of the ecological crisis

- and the mutual exploration, from the perspective of different world views and religious myths, of contemporary insight into the origins of the universe and the earth, the functioning of the ecological systems of the earth, and the dependence of the human and other-than-human community on these fragile systems, in South Africa is only really starting. It has its roots in various movements, for example, the struggle against apartheid, the ecumenical churches movement, interreligious councils, ecological care in local communities, and environmental organisations such as Earthlife Africa. The 'God moment' which was the birth of SAFCEI is described by the Green Bishop of the Anglican Church, Bishop Geoff Davies, is still happening and unfolding.

The birth and the growth of the strong new organisation, SAFCEI, in a time of political and economic despair in South Africa while ecological disaster and injustice are not receiving the necessary attention from government, creates not only a space for, but also the impetus for interreligious earth dialogue as prophetic witness for 'peace for life'. This interreligious happening needs to be explored further, so as to strengthen the spiritual and theological, yet very practical and public work of earth dialogue in the service of earth-keeping and ecological justice in Southern Africa. 